\title{
ANALISIS KONTRIBUSI SIKAP ILMIAH, MOTIVASI BELAJAR DAN KEMANDIRIANBELAJAR TERHADAP PRESTASI BELAJAR MAHASISWA PRODI PENDIDIKAN FISIKA STKIP PGRI PONTIANAK
}

\author{
Wahyudi \\ Prodi Pendidikan Fisika STKIP PGRI Pontianak \\ wahyudi.kakap@gmail.com
}

\begin{abstract}
ABSTRAK
Penelitian ini bertujuan untuk mengetahui seberapa besar kontribusi sikap ilmiah, motivasi berprestasi dan kemandirian belajar terhadap prestasi belajar mahasiswa prodi pendidikan fisika STKIP PGRI Pontianak. Sampel penelitian berjumlah 3 kelas yang diambil dengan teknik cluster random sampling dan mewakili semua mahasiswa Prodi Pendidikan Fisika tiap jenjang semester. Penelitian ini menggunakan metode deskriptif-assosiatif yang menggambarkan korelasi dan kontribusi antara variabel bebas (sikap ilmiah, motivasi belajar dan kemandirian belajar) terhadap variabel terikat (prestasi belajar) terutama kontribusi variabel bebas terhadap variabel terikat. Instrumen pengumpul data berupa angket sikap ilmiah, motivasi belajar dan kemandirian belajar. Data pretasi belajar mahasiswa diambil dari data indeks prestasi komulatif mahasiswa. Hasil penelitian menunjukkan sikap ilmiah, motivasi belajar dan kemandirian belajar berkorelasi positif dan signifikan terhadap prestasi belajar. Sikap ilmiah berkontribusi 1,00\%, motivasi belajar berkontribusi 7,10\%, kemandirian belajar berkontribusi $5,10 \%$, sikap ilmiah, motivasi dan kemandirian belajar berkontribusi $8,80 \%$ terhadap prestasi belajar mahasiswa. Disarankan bagi para dosen untuk memberikan motivasi mahasiswa dalam belajar, melatih sikap ilmiah mahasiswa dan berusaha membentuk karakter mahasiswa yang mandiri dalam belajar. Bagi penelitian lanjutan disarankan untuk melihat pengaruh sikap ilmiah, motivasi belajar dan kemandirian belajar terhadap prestasi belajar mahasiswa.
\end{abstract}

Kata Kunci: Kontribusi, Sikap Ilmiah, Motivasi Belajar, Kemandirian Belajar, Prestasi Belajar

\section{PENDAHULUAN}

Belajar merupakan suatu usaha yang dilakukan pebelajar (dalam hal ini mahasiswa) melalui suatu aktivitas untuk mencapai kepandaian atau mendapatkan pengetahuan. Belajar merupakan proses yang berlangsung dalam jangka waktu lama melalui latihan maupun pengalaman yang membawa kepada perubahan diri. Dalam proses belajar, perubahan terjadi melalui tahapan-tahapan dan keberhasilannya bergantung pada faktor-faktor yang mempengaruhinya.

Proses belajar dipengaruhi berbagai komponen, sehingga secara otomatis komponen-komponen tersebut juga menentukan hasil belajar mahasiswa. Dimyati dan Mudjiono
(2009: 11), memaparka bahwa pada dasarnya faktor-faktor yang mempengaruhi hasil belajar itu ada dua yaitu faktor internal (faktor yang berasal dari dalam diri mahasiswa) dan faktor eksternal (faktor yang berasal dari luar diri mahasiswa). Ditinjau dari sudut pandang mahasiswa, faktor eksternal tersebut adalah dosen sebagai pembina mahasiswa belajar, prasarana dan sarana pembelajaran, kebijakan penilaian, lingkungan sosial mahasiswa di sekolah dan kurikulum sekolah. Faktor internal yang mempengaruhi prestasi belajar fisika yaitu faktor fisik dan psikis. Faktor psikis mencakup aspek intelektual dan non intelektual. Aspek intelektual seseorang dapat berupa intelektual potensial ataupun intelektual nyata. Intelektual 
potensial dimiliki setiap individu dengan kadar yang berbeda-beda, termasuk di dalamnya kecerdasan dan bakat. Sedangkan intelektual nyata berupa prestasi yang dimiliki sebelumnya. Aspek non intelektual mencakup banyak hal di antaranya sikap, kebiasaan, minat, persepsi, harapan, motivasi, stabilitas emosi, kepribadian, watak dan karakter.

Faktor-faktor dalam diri mahasiswa ini berinteraksi dan saling terkait satu sama lain yang kemudian memberikan pengaruh terhadap hasil belajar, termasuk berlaku juga pada mata pelajaran fisika. Faktor-faktor tersebut perlu mendapatkan perhatian dan perlakuan yang tepat terlebih juga jika faktor tersebut akhirnya berpengaruh juga terhadap prestasi belajar mahasiswa. Salah satu faktor dari dalam diri mahasiswa yang mempengaruhi prestasi belajarnya adalah sikap ilmiah yang dimiliki mahasiswa. Sikap ilmiah adalah tingkat kesesuaian tingkah laku mahasiswa terhadap proses belajar mengajar yang memiliki ciri-ciri sebagai berikut: rasa ingin tahu, tidak dapat menerima kebenaran tanpa bukti, jujur, teliti, menghargai pendapat orang lain, dan sanggup menerima gagasan baru dan semangat baru. Hasil penelitian yang dilakukan Wahyudi (2011) menyimpulkan bahwa sikap ilmiah mahasiswa mempengaruhi prestasi belajar mahasiswa baik pada aspek kognitif, afektif maupun psikomotorik. Mahasiswa yang memiliki sikap ilmiah yang tinggi memiliki prestasi belajar yang baik dari pada mahasiswa yang memiliki sikap ilmiah yang rendah.

Selain sikap ilmiah, faktor yang mempengaruhi prestasi belajar mahasiswa lainnya adalah motivasi belajar. Berelson dan Steiner dalam Angkowo dan Kosasih (2007: 34) berpendapat bahwa motivasi merupakan suatu usaha sadar untuk mempengaruhi prilaku seseorang, agar mengarah pada tercapainya tujuan organisasi. Kemudian Purwanto (1990:
71) mengatakan motivasi adalah pendorong seseorang untuk melakukan suatu usaha yang disadari untuk mempengaruhi tingkah laku, agar hatinya tergerak untuk bertindak sehingga mencapai hasil atau tujuan tertentu. Sumber munculnya motivasi belajar ada tiga sebagai mana disampaikan oleh Angkowo dan Kosasih (2007: 43) yaitu: (1) rasa ingin tahu (couriosity) atas stimulus (rangsangan) yang baru, kompleks dan tidak biasa, (2) keinginan untuk berprestasi (need achievement) untuk mencapai sesuatu, menguasai sesuatu, dan menghasilkan sesuatu, (3) rasa percaya diri (self afficacy/confidence), yaitu keyakinan tentang kemampuan mencapai sukses atau menghindari kegagalan. Jika rasa ingin tahu, keinginan untuk berprestasi, dan rasa percaya diri siswa sangat besar maka dapat dikatakan bahwa siswa tersebut memiliki motivasi yang besar. Hasil penelitian yang dilakukan oleh Wadji (2011) menyimpulkan bahwa motivasi belajar dapat mempengaruhi prestasi belajar mahasiswa. Mahasiswa yang memiliki motivasi belajar yang tinggi memiliki prestasi belajar yang baik daripada mahasiswa yang memiliki motivasi belajar yang rendah.

Faktor lain yang mempengaruhi prestasi belajar mahasiswa adalah kemandirian belajar yang dimiliki mahasiswa. Hubungan kemandirian dengan kegiatan belajar diungkapkan oleh Gie (1983: 70), bahwa kemandirian belajar adalah suatu situasi yang memungkinkan seseorang memperoleh pengetahuan dan pemahaman serta keterampilan atas prakarsa atau inisiatif, kepercayaan diri dan tanggung jawabnya. Ditambahkannya, dengan adanya kenyataan kodrati manusia untuk terus belajar sepanjang hidup (life long education) maka kemandirian belajar merupakan situasi yang sangat penting, mengingat hal ini mejadi suatu kebutuhan seseorang. Hasil penelitian yang dilakukan oleh Junjunan (2009) menyimpulkan bahwa kemandirian belajar 
memiliki kontrinusi yang positif dan signifikan terhadap prestasi belajar siswa.

Berdasarkaan uraian di atas dapat dikatakan bahwa sikap ilmiah, motivasi belajar dan kemandirian belajar dapat mempengaruhi dan berkontribusi pada prestasi belajar mahasiswa khususnya dalam mempelajari fisika. Sehingga penelitian ini dilakukan bertujuan untuk mengetahui seberapa besar kontribusi sikap ilmiah, motivasi belajar dan kemandirian belajar terhadap prestasi belajar mahasiswa Prodi Pendidikan Fisika STKIP PGRI Pontianak

\section{METODE PENELITIAN}

Metode penelitian yang akan digunakan dalam penelitian ini adalah metode kuantitatif berbentuk deskriptif assosiatif. Populasi dalam penelitian ini adalah seluruh mahasiswa program studi pendidikan fisika yang aktif mengikuti perkuliahan yang terdiri dari mahasiswa semester dua (3 kelas), mahasiswa semester empat (3 kelas) dan mahasiswa semester enam (2 kelas). Tiap jenjang semester dipilih 1 kelas dengan teknik random, sehingga sampel penelitian berjumlah 3 kelas yang mewakili semua mahasiswa tiap jenjang semester.

Teknik pengumpulan data yang digunakan dalam penelitian ini ada dua yaitu teknik non tes dan dokumentasi. Angket yang digunakan terdiri dari angket sikap ilmiah, angket motivasi belajar dan kemandirian belajar. Semua angket diuji cobakan untuk mengetahui tingkat validitas dan reliabilitas butir angket. Semua angket yang digunakan memiliki kriteria valid dengan tingkat reliabilitas yang tinggi. Dokumentasi dilakukan dengan cara mengumpulkan data prestasi belajar mahasiswa dalam bentuk daftar indek prestasi belajar.

Pengujian hipotesis dilakukan menggunakan rumus korelasi $r$ Spearman Rank dengan bantuan program SPSS versi 16 pada Output model summary. Selanjutnya nilai koefisien korelasi akan dikonfirmasi melalui kriteria yang ditentukan oleh Arikunto (2002:245). Besarnya kontribusi variabel bebas sikap ilmiah, motivasi belajar dan kemandirian belajar terhadap prestasi belajar dihitung melalui koefisien determinasi. Pada Output Program SPSS, koefisien determinasi dapat dilihat pada tabel model summary pada kolom $R$ Square. Uji signifikansi korelasi variabel bebas terhadap variabel terikat dilihat dari uji Fisher pada tabel ANOVA pada output program SPSS. Uji regresi dilakukan untuk memprediksikan besarnya kenaikan variabel terikat yang diakibatkan oleh kenaikan variabel bebas. Uji regresi dilihat dari hasil ouput program SPSS pada tabel Coeficience, berdasarkan nilai konstanta dan nilai koefisien masing-masing variabel bebas.

\section{HASIL PENELITIAN DAN PEMBAHASAN}

Deskripsi data sikap ilmiah, motivasi belajar dan kemandirian belajar mahasiswa program studi pendidikan fisika yang meliputi mahasiswa semester dua, empat dan enam ditampilakan pada Tabel 1 dibawah ini. 
Tabel 1. Deskripsi Data Sikap Ilmiah, Motivasi Belaajr dan Kemandirian Belajar

\begin{tabular}{lcccc}
\hline \multirow{2}{*}{$\begin{array}{c}\text { Descriptive } \\
\text { Statistic }\end{array}$} & $\begin{array}{c}\text { Sikap } \\
\text { Ilmiah }\end{array}$ & $\begin{array}{c}\text { Motivasi } \\
\text { Belajar }\end{array}$ & $\begin{array}{c}\text { Kemandirian } \\
\text { Belajar }\end{array}$ & Indek Prestasi \\
\cline { 2 - 5 } & 92,06 & 97,41 & 129,74 & 3,13 \\
\hline Mean & 10,05 & 7,59 & 11,69 & 0,40 \\
Standard Deviation & 101,07 & 57,55 & 136,57 & 0,16 \\
Sample Variance & 68,00 & 53,00 & 61,00 & 1,88 \\
Range & 41,00 & 69,00 & 88,00 & 2,12 \\
Minimum & 109,00 & 122,00 & 149,00 & 4,00 \\
Maximum & 160,00 & 160,00 & 160,00 & 160,00 \\
Count & & & & \\
\hline
\end{tabular}

Pada Tabel 1 dapat dilihat bahwa rerata skor sikap ilmiah mahasiswa sebesar 92,06 dengan skor maksimum sikap ilmiah mahasiswa adalah 109,00 dan skor minimum 41,00. Ukuran penyimpangan dari skor ratarata diketahui sebesar 10,05. Rerata skor motivasi belajar mahasiswa sebesar 97,41 dengan skor maksimum motivasi belajar mahasiswa adalah 122 dan skor minimum 69. Ukuran penyimpangan dari skor rata-rata diketahui sebesar 7,59. Rerata skor kemandirian belajar mahasiswa sebesar 129,72 dimana skor maksimum kemandirian belajar mahasiswa adalah 149,00 dan skor minimum
88. Ukuran penyimpangan dari skor rata-rata diketahui sebesar 11,69. Rerata indeks prestasi belajar mahasiswa sebesar 3,13 dimana nilai maksimum indeks prestasi belajar mahasiswa sebesar 4,00 dan nilai minimum sebesar 2,12. Ukuran penyimpangan dari nilai rata-rata diketahui sebesar 0,40. Dari informasi yang diperoleh dari data pada Tabel 1, maka masingmasing data sikap ilmiah, motivasi belajar, kemandirian belajar dan prestasi belajar mahasiswa dikelompokkan berdasarkan kategori tinggi, sedang dan rendah yang ditampilkan pada Gambar 1.

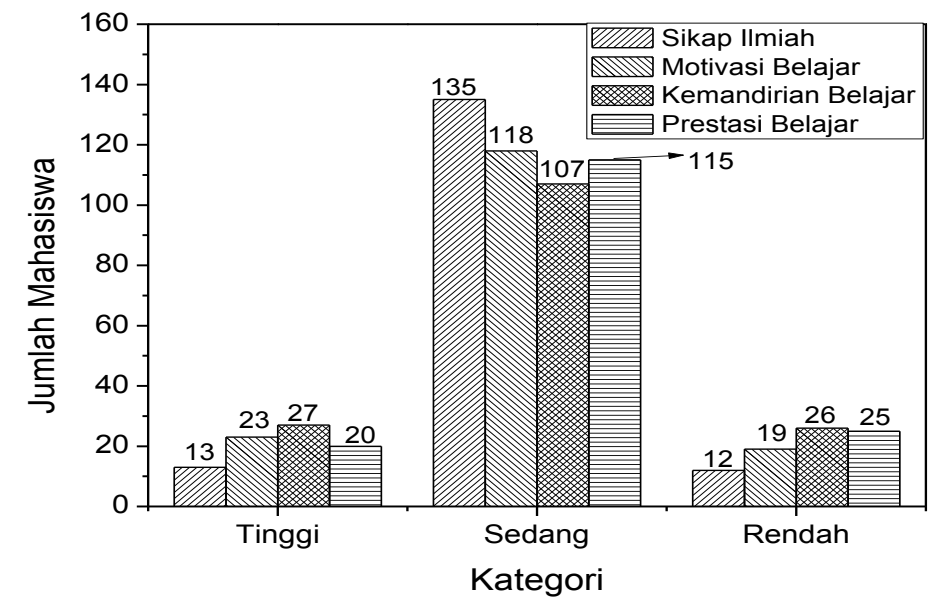

Gambar 1. Grafik jumlah mahasiswa yang memiliki sikap ilmiah, motivasi belajar, kemandirian belajar dan prestasi belajar dengan kategori tinggi sedang dan rendah 
Berdasarkan Gambar 1, diketahui bahwa sikap ilmiah mahasiswa didominasi oleh kategori sedang yakni sebanyak 135 (84,38\%) mahasiswa dari 160 mahasiswa. Mahasiswa yang memiliki kategori sikap ilmiah tinggi hanya terdapat $13(8,13 \%)$ mahasiswa. Jumlah mahasiswa dengan kategori sikap ilmiah rendah berjumlah 12 (7,49\%) mahasiswa. Begitu juga dengan motivasi belajar mahasiswa yang didominasi oleh kategori sedang yakni sebanyak 118 (73,75\%) mahasiswa dari 160 mahasiswa. Mahasiswa yang memiliki kategori motivasi belajar tinggi hanya terdapat 23 $(14,38 \%)$ mahasiswa sedangkan jumlah mahasiswa dengan kategori motivasi belajar rendah berjumlah 19 (11,87\%) mahasiswa. Mahasiswa yang memiliki kategori kemandirian belajar tinggi hanya terdapat 27 $(16,88 \%)$ mahasiswa sedangkan jumlah mahasiswa dengan kategori kemandirian belajar rendah berjumlah $16 \quad(16,24 \%)$ mahasiswa dan sisanya $107 \quad(66,88 \%)$ mahasiswa memiliki kategori kemandirian belajar yang sedang. Prestasi belajar mahasiswa berdasarkan indek prestasi kumulatif sebagian besar $(71,88 \%)$ tergolong kategori sedang.

Uji korelasi digunakan untuk mengetahui arah dan besarnya derajat hubungan serta besaranya kontribusi antara variabel bebas yakni sikap ilmiah, motivasi belajar dan kemandirian belajar terhadap variabel terikat yakni pretasi belajar mahasiswa. Sementara uji regresi digunakan untuk memprediksikan hubungan antar variabel dan besarnya kenaikan variabel terikat yang yang ditentukan oleh kenaikan nilai dari variabel bebas (variabel prediktor). Pengujian hipotesis menggunakan bantuan program SPSS versi 16. Hasil analisis korelasi dan regresi antara variabel bebas sikap ilmiah dengan variabel terikat prestasi belajar ditampilkan pada Tabel berikut ini.

Tabel 2a. Hasil analisis korelasi sikap ilmiah dengan prestasi belajar

\begin{tabular}{ccccc}
\hline Model & $R$ & $R$ square & Adjusted $R$ square & $\begin{array}{c}\text { Std. Error of The } \\
\text { Estimate }\end{array}$ \\
\hline \hline 1 & 0.101 & 0.010 & 0.004 & 0.39599 \\
\hline
\end{tabular}

Tabel 2b. Hasil ANOVA uji signifikansi korelasi sikap ilmiah dengan prestasi belajar

\begin{tabular}{cccccc}
\hline Model & Sum of Squares & $d f$ & Mean Square & $F$ & Sig \\
\hline \hline Regression & 0.254 & 1 & 0.254 & 1.617 & 0.205 \\
\hline Residual & 24.775 & 158 & 0.157 & & \\
\hline Total & 25.029 & 159 & & & \\
\hline
\end{tabular}

Tabel 2c. Hasil uji regresi sikap ilmiah dengan prestasi belajar

\begin{tabular}{ccccccc}
\hline \multirow{2}{*}{ Model } & \multicolumn{2}{c}{$\begin{array}{c}\text { Unstandarized } \\
\text { Coefficients }\end{array}$} & $\begin{array}{c}\text { Standarized } \\
\text { Coefficients }\end{array}$ & \multirow{2}{*}{$t$} & \multirow{2}{*}{ Sig. } \\
\cline { 3 - 6 } & \multicolumn{1}{c}{ B } & Std.Error & Beta & & \\
\hline \hline \multirow{2}{*}{1} & (Constant) & 2.761 & 0.289 & & 9.544 & 0.000 \\
\cline { 2 - 7 } & Sikap Ilmiah & 0.004 & 0.003 & 0.101 & 1.272 & 0.205 \\
\hline
\end{tabular}

Berdasarkan Tabel 2a, dapat diketahui nilai keofisien korelasi antara sikap ilmiah dengan prestasi belajar adalah 0,101 dan berkorelasi positif. Berdasarkan kriteria yang 
dikemukakan oleh Arikunto (2002: 245), maka korelasi antara sikap ilmiah dengan prestasi belajar tergolong sangat rendah. Kemudian dari Tabel 2a, diketahui nilai $R$ square sebesar 0,010 , dengan kata lain sikap ilmiah hanya memberikan kontribusi $1,00 \%$ terhadap prestasi belajar. Hasil Uji keberartian (signifikan) korelasi antara sikap ilmiah dengan prestasi belajar dapat diketahui dari nilai Sig. pada Tabel 2b yakni sebesar 0,205 atau lebih besar dari taraf signifikansi yang digunakan dalam penelitian ini yakni sebesar 5\% $(0,05)$. Sehingga dapat dikatakan korelasi antara sikap ilmiah dengan prestasi belajar tidak signifikan. Dari Tabel 2c dapat dibuat presamaan garis regresi. Diketahui kontanta sebesar 2,761 dan harga koefisien X sebesar 0,004, sehingga persamaan regresinya adalah $\mathrm{Y}=2,761+0,004 \mathrm{X}$. Dengan demikian dapat dikatakan jika nilai sikap ilmiah naik sebesar 1 satuan maka prestasi belajar akan naik sebesar 2,765 satuan.

Tabel 3a Hasil analisis korelasi motivasi belajar dengan prestasi belajar

\begin{tabular}{ccccc}
\hline Model & $R$ & $R$ square & Adjusted $R$ square & Std. Error of The Estimate \\
\hline \hline 1 & 0.266 & 0.071 & 0.065 & 0.38371 \\
\hline
\end{tabular}

Tabel 3b Hasil ANOVA uji signifikansi korelasi motivasi belajar dengan prestasi belajar

\begin{tabular}{cccccc}
\hline Model & Sum of Squares & $d f$ & Mean Square & $F$ & Sig \\
\hline \hline Regression & 1.765 & 1 & 1.765 & 11.990 & 0.001 \\
\hline Residual & 23.263 & 158 & 0.147 & & \\
\hline Total & 25.029 & 159 & & & \\
\hline
\end{tabular}

Tabel 3c Hasil uji regresi motivasi belajar dengan prestasi belajar

\begin{tabular}{ccccccc}
\hline \multirow{2}{*}{ Model } & \multicolumn{2}{c}{ Unstandarized Coefficients } & \multicolumn{2}{c}{$\begin{array}{l}\text { Standarized } \\
\text { Coefficients }\end{array}$} & \multirow{2}{*}{$t$} & \multirow{2}{*}{ Sig. } \\
\cline { 3 - 6 } & $B$ & Std.Error & Beta & & \\
\hline \multirow{2}{*}{1} & (Constant) & 1.774 & 0.392 & & 4.526 & 0.000 \\
\cline { 2 - 6 } & Motivasi & 0.014 & 0.004 & 0.266 & 3.463 & 0.001 \\
\hline
\end{tabular}

Berdasarkan Tabel 3a, dapat diketahui nilai keofisien korelasi antara motivasi belajar dengan prestasi belajar adalah 0,266 dan berkorelasi positif. Berdasarkan kriteria yang dikemukakan oleh Arikunto (2002: 245), maka korelasi antara motivasi belajar dengan prestasi belajar tergolong rendah. Kemudian dari Tabel 3a, diketahui nilai $R$ square sebesar 0,071 , dengan kata lain motivasi belajar hanya memberikan kontribusi $7,10 \%$ terhadap prestasi belajar. Hasil Uji keberartian (signifikan) korelasi antara motivasi belajar dengan prestasi belajar dapat diketahui dari nilai Sig. pada Tabel 3b yakni sebesar 0,001 atau lebih kecil dari taraf signifikansi yang digunakan dalam penelitian ini yakni sebesar $5 \%(0,05)$. Sehingga dapat dikatakan korelasi antara motivasi belajar dengan prestasi belajar signifikan. Dari Tabel 5.8c dapat dibuat presamaan garis regresi. Diketahui kontanta sebesar 1,774 dan harga koefisien $\mathrm{X}$ sebesar 0,014 , sehingga persamaan regresinya adalah $\mathrm{Y}=1,774+0,014 \mathrm{X}$. Dengan demikian dapat dikatakan jika nilai motivasi belajar naik sebesar 1 satuan maka prestasi belajar akan naik sebesar 1,788 satuan. 
Tabel 4a. Hasil analisis korelasi kemandirian belajar dengan prestasi belajar

\begin{tabular}{ccccc} 
Model & $R$ & $R$ square & Adjusted $R$ square & Std. Error of The Estimate \\
\hline 1 & 0.226 & 0.051 & 0.045 & 0.38773
\end{tabular}

Tabel 4b. Hasil ANOVA uji signifikansi korelasi kemandirian belajar dengan prestasi belajar

\begin{tabular}{cccccc}
\hline Model & Sum of Squares & $d f$ & Mean Square & $F$ & Sig \\
\hline \hline Regression & 1.276 & 1 & 1.276 & 8.491 & 0.004 \\
\hline Residual & 23.752 & 158 & 0.150 & & \\
\hline Total & 25.029 & 159 & & & \\
\hline
\end{tabular}

Tabel 4c Hasil uji regresi kemandirian belajar dengan prestasi belajar

\begin{tabular}{ccccccc}
\hline \multirow{2}{*}{ Model } & \multicolumn{2}{c}{$\begin{array}{c}\text { Unstandarized } \\
\text { Coefficients }\end{array}$} & $\begin{array}{c}\text { Standarized } \\
\text { Coefficients }\end{array}$ & \multirow{2}{*}{$t$} & \multirow{2}{*}{ Sig. } \\
\cline { 3 - 7 } & & $B$ & Std.Error & Beta & & \\
\hline \hline \multirow{2}{*}{1} & (Constant) & 2.132 & 0.343 & & 6.220 & 0.000 \\
\cline { 2 - 7 } & Kemandirian & 0.008 & 0.003 & 0.226 & 2.914 & 0.004 \\
\hline
\end{tabular}

Berdasarkan Tabel 4a, dapat diketahui nilai keofisien korelasi antara kemandirian belajar dengan prestasi belajar adalah 0,226 dan berkorelasi positif. Berdasarkan kriteria yang dikemukakan oleh Arikunto (2002: 245), maka korelasi antara kemandirian belajar dengan prestasi belajar tergolong rendah. Kemudian dari Tabel 4a, diketahui nilai $R$ square sebesar 0,051, dengan kata lain kemandirian belajar hanya memberikan kontribusi $5,10 \%$ terhadap prestasi belajar. Hasil Uji keberartian (signifikan) korelasi antara kemandirian belajar dengan prestasi belajar dapat diketahui dari nilai Sig. pada
Tabel 4b yakni sebesar 0,004 atau lebih kecil dari taraf signifikansi yang digunakan dalam penelitian ini yakni sebesar $5 \% \quad(0,05)$. Sehingga dapat dikatakan korelasi antara kemandirian belajar dengan prestasi belajar signifikan. Dari Tabel 4c dapat dibuat presamaan garis regresi. Diketahui kontanta sebesar 2.132 dan harga koefisien X sebesar 0,008 , sehingga persamaan regresinya adalah $\mathrm{Y}=2,132+0,008 \mathrm{X}$. Dengan demikian dapat dikatakan jika nilai kemandirian belajar naik sebesar 1 satuan maka prestasi belajar akan naik sebesar 2,140 satuan.

Tabel 5a Hasil analisis korelasi sikap ilmiah, motivasi dan kemandirian belajar dengan prestasi belajar

\begin{tabular}{ccccc}
\hline Model & $R$ & $R$ square & Adjusted $R$ square & Std. Error of The Estimate \\
\hline \hline 1 & 0.296 & 0.088 & 0.070 & 0.38257 \\
\hline
\end{tabular}

Tabel 5b Hasil ANOVA uji signifikansi korelasi sikap ilmiah, motivasi dan kemandirian belajar dengan prestasi belajar

\begin{tabular}{cccccc}
\hline Model & Sum of Squares & $d f$ & Mean Square & $F$ & Sig \\
\hline \hline Regression & 2.197 & 3 & 0.732 & 5.004 & 0.002 \\
\hline Residual & 22.832 & 156 & 0.146 & & \\
\hline
\end{tabular}


Wahyudi, Analisis Kontribusi Sikap Ilmiah...

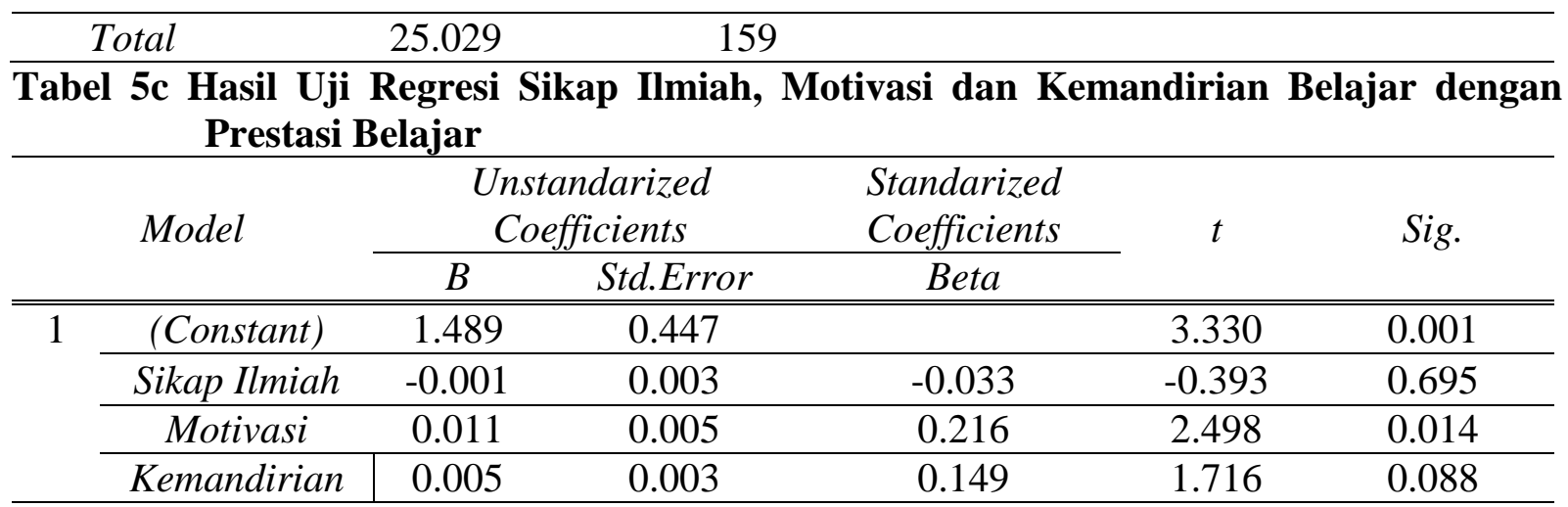

Berdasarkan Tabel 5a, dapat diketahui nilai keofisien korelasi antara sikap ilmiah, motivasi dan kemandirian belajar dengan prestasi belajar adalah 0,296 dan berkorelasi positif. Berdasarkan kriteria yang dikemukakan oleh Arikunto (2002: 245), maka korelasi antara sikap ilmiah, motivasi dan kemandirian belajar dengan prestasi belajar tergolong rendah. Kemudian dari Tabel 5a, diketahui nilai $R$ square sebesar 0,088 , dengan kata lain sikap ilmiah, motivasi dan kemandirian belajar hanya memberikan kontribusi $8,80 \%$ terhadap prestasi belajar. Hasil Uji keberartian (signifikan) korelasi antara sikap ilmiah, motivasi dan kemandirian belajar dengan prestasi belajar dapat diketahui dari nilai Sig. pada Tabel 5b yakni sebesar 0,002 atau lebih kecil dari taraf signifikansi yang digunakan dalam penelitian ini yakni sebesar 5\% $(0,05)$. Sehingga dapat dikatakan korelasi antara sikap ilmiah, motivasi dan kemandirian belajar dengan prestasi belajar signifikan. Dari Tabel $5 c$ dapat dibuat presamaan garis regresi. Diketahui kontanta sebesar 1,489 dan harga koefisien X1 (sikap ilmiah) sebesar -0,001, harga koefisien X2 (motivasi belajar) sebesar 0,011 dan harga koefisien X3 (kemandirian belajar) sebesar 0,005 sehingga persamaan regresinya adalah $\mathrm{Y}=1,489$ $0,001 \mathrm{X} 1+0,011 \mathrm{X} 2+0,005 \mathrm{X} 3$. Dari persamaan tersebut dapat dipahami bahwa kenaikan 1 satuan nilai sikap ilmiah justru akan mengurangi nilai prestasi belajar. Dengan demikian dapat dikatakan jika nilai sikap ilmiah, motivasi belajar dan kemandirian belajar naik sebesar 1 satuan maka prestasi belajar akan naik sebesar 1,504 satuan.

\section{Kontribusi Sikap Ilmiah terhadap Prestasi Belajar Mahasiswa}

Analisis data menunjukkan bahwa mahasiswa secara umum memiliki sikap ilmiah dengan kategori sedang. Hal ini dapat dilihat dari persentase kategori sikap ilmiah mahasiswa yaitu sebesar $84,38 \%$ dengan kategori sedang dan hanya sebesar $8,13 \%$ mahasiswa yang memiliki sikap ilmiah tinggi. Sehingga sikap ilmiah ini harus dapat terus ditingkatkan untuk merangsang sikap positif mahasiswa dalam belajar yang kemudian akan meningkatkan prestasi belajar mahasiswa. Sikap ilmiah merupakan faktor internal yang mempengaruhi hasil belajar mahasiswa. Mahasiswa yang mempunyai sikap ilmiah tinggi cenderung lebih mudah dalam belajar, mudah dalam menerima dan mengolah informasi serta terampil dalam memecahkan masalah yang diberikan. Sedangkan mahasiswa yang memiliki sikap ilmiah rendah kurang menguasai pelajaran secara sepenuhnya, sehingga prestasi belajarnya juga kurang baik. Hal ini disebabkan, karena kesadaran mereka yang kurang dalam menghadapi permasalahan yang diberikan. Sikap ingin tahu, kritis, 
objektif, tekun dan terbuka dalam memecahkan suatu permasalahan tidak dioptimalkan mahasiswa selama proses pembelajaran. Sehingga hasil prestasi belajar yang mereka peroleh juga rendah.

Hasil penelitian ini menunjukkan sikap ilmiah mahasiswa memiliki berkorelasi positif terhadap terhadap prestasi belajar mahasiswa, namun tidak signifikan. Indeks korelasi sebesar 0,101 menunjukkan korelasi antara sikap ilmiah dengan prestasi belajar tergolong sangat rendah bahkan tidak berkorelasi sama sekali. Sikap ilmiah hanya memberikan kontribusi $1,00 \%$ terhadap prestasi belajar. Hasil penelitian ini bertentangan dengan penelitian yang dilakukan Wahyudi (2011), yang menemukan bahwa sikap ilmiah memiliki pengaruh yang signifikan dalam meningkatkan prestasi belajar mahasiswa. Secara teoritis, mahasiswa yang memiliki sikap ilmiah yang tinggi akan memiliki ketelitian yang tinggi, rasa ingin tahu yang besar, kejujuran yang tinggi dan tekun dalam belajar. Sehingga mahasiswa yang memiliki sikap ilmiah yang tinggi justru akan memiliki prestasi belajar yang tinggi pula. Namun dari hasi penelitian ini, sikap ilmiah hanya memberikan kontribusi $1,00 \%$ terhadap prestasi belajar mahasiswa dan 99\% disebabkan oleh faktor lain.

Salah satu faktor yang menyebabkan kontribusi sikap ilmiah mahasiswa tergolong rendah terhadap prestasi belajar mahasiswa adalah rata-rata sikap ilmiah mahasiswa tergolong sedang $(83,38 \%)$ dan hanya $8,13 \%$ mahasiswa yang memiliki sikap ilmiah yang tinggi. Hal ini menjadikan sikap ilmiah bukan faktor utama yang menjadikan prestasi belajar mahasiswa meningkat. Sikap ilmiah mahasiswa yang tergolong sedang memungkinkan masih terdapat mahasiswa yang kurang jujur dalam belajar, kurang tekun dalam belajar, rasa ingin tahu yang belum kuat dan ketelitian yang belum tinggi. Hal ini menjadikan sikap ilmiah belum cukup berkontribusi terhadap prestasi belajar mahasiswa.

\section{Kontribusi Motivasi Belajar terhadap Prestasi Belajar Mahasiswa}

Motivasi belajar mahasiswa secara unum tergolong sedang. Hal ini ditunjukkan pada analisis data bahwa persentase mahasiswa yang memiliki kategori sedang sebesar $73,75 \%$ dan hanya hanya sebesar $14,38 \%$ mahasiswa yang memiliki motivasi belajar yang tinggi. Motivasi belajar ini harus dapat terus ditingkatkan dengan memaksimalkan peranan dosen sebagai motivator mahasiswa dalam belajar. Mahasiswa yang memiliki motivasi yang tinggi akan memudahkannya dalam belajar sehingga akan berdampak pada prestasi belajar yang lebih baik.. Menurut Purwanto (1990: 71), motivasi adalah pendorong seseorang untuk melakukan suatu usaha yang disadari untuk mempengaruhi tingkah laku, agar hatinya tergerak untuk bertindak sehingga mencapai hasil atau tujuan tertentu". Jadi dari ungkapan tersebut dapat dipahami bahwa prestasi belajar yang merupakan tujuan dari proses belajar mengajar didalam kelas akan diperoleh maksimal apabila seseorang tersebut memiliki motivasi yang tinggi. Fungsi motivasi bagi mahasiswa adalah: (1) mendorong mahasiswa untuk berbuat dalam hal ini belajar, (2) menentukan arah perbuatan mahasiswa, (3) membuat mahasiswa memiliki strategi untuk mencapai kesuksesan dalam belajar, (4) membuat mahasiswa berani berpartisipasi, (5) membangkitkan hasrat ingin tahu, (6) menyempurnakan perhatian mahasiswa.

Hasil penelitian ini menunjukkan motivasi belajar mahasiswa memiliki berkorelasi positif dan signifikan terhadap terhadap prestasi belajar mahasiswa. Indeks korelasi sebesar 0,266 menunjukkan korelasi antara motivasi belajar dengan prestasi belajar tergolong rendah. Motivasi belajar mahasiswa 
hanya memberikan kontribusi $7,10 \%$ terhadap prestasi belajar, sedikit lebih besar daripada kontribusi sikap ilmiah terhadap prestasi belajar mahasiswa yang hanya $1,00 \%$. Untuk itu, para dosen hendaknya memberikan motivasi yang tinggi kepada mahasiswa dalam belajar. Dalam pembelajaran, menurut Angkowo dan Kosasih (2007: 44), dosen dapat memberikan motivasi belajar melalui dua cara, yaitu: (1) meningkatkan mutu pembelajaran, untuk tujuan itu maka diperlukan lima macam teknologi pembelajaran, yakni berfikir sistematis, desain sistem, ilmu pengetahuan yang bermutu, managemen perubahan, dan teknologi pembelajaran; (2) mempengaruhi harapan mahasiswa, dengan demikian mahasiswa percaya bahwa keterlibatannya dalam proses untuk suatu keberhasilan. Jika dosen dapat meningkatkan mutu pembelajaran dan mampu mempengaruhi harapan mahasiswa maka dosen tersebut sudah memberikan motivasi belajar kepada mahasiswa. Untuk mengetahui motivasi belajar mahasiswa, ada beberapa indikator, yakni; (1) keinginan mencapai hasil yang optimal, (2) keinginan untuk meningkatkan pengetahuan, dan (3) rasa percaya diri dan kepuasan.

\section{Kontribusi Kemandirian Belajar terhadap Prestasi Belajar Mahasiswa}

Faktor lain yang mempengaruhi prestasi belajar mahasiswa adalah kemandirian belajar. Hasil analisis data menunjukkan mahasiswa secara umum memiliki kemandirian belajar dengan kategori sedang $(66,88 \%)$ dan hanya $16,88 \%$ yang memiliki kategori kemandirian belajar tinggi. Kemandirian belajar merupakan kemandirian seseorang dalam kegiatan belajarnya. Kemandirian belajar mendorong seseorang mengambil pronsip segala aspek kegiatan belajar. Kemandirian belajar secara mandiri terwujud dalam penentuan tujuan, keteraturan serta kesungguhan mendalami bahan pelajaran dalam memilih metode serta sarana, disiplin dengan aturan dan perencanaan dan berinisiatif untuk meningkatkan prestasi belajarnya, percaya diri dan optimis terhadap hasil yang dicapai serta tanggungjawab.

Berdasarkan hasil analisis diketahui bahwa kemandirian belajar berkorelasi positif dan signifikan terhadap prestasi belajar mahasiswa. Indeks korelasi sebesar 0,226 menunjukkan korelasi antara motivasi belajar dengan prestasi belajar tergolong rendah. Kemandirian belajar mahasiswa hanya memberikan kontribusi $5,10 \%$ terhadap prestasi belajar dan $94,90 \%$ dikontribusikan oleh faktor lainnya. Nilai tersebut sedikit lebih besar daripada kontribusi sikap ilmiah terhadap prestasi belajar mahasiswa namun lebih kecil daripada kontribusi motivasi belajar terhadap prestasi belajar mahasiswa.

Salah satu faktor yang menyebabkan kemandirian belajar tidak memberikan kontribusi yang cukup besar terhadap prestasi belajar mahasiswa adalah masih belum tergolong tingginya kemandiran belajar mahasiswa. Masih terdapat mahasiswa yang mengandalkan temannya dalam belajar sehingga menjadikan mahasiswa kurang berusaha untuk mendapatkan pengetahuan dengan kemampuannya sendiri. Hal ini dapat juga diamati dalam proses pengerjaan tugas dan pelaksanaan ujian, dimananmasih terdapat mahasiswa yang mengandalkan temannya. Walaupun demikian, berdasarkan hasil penelitian ini, kemandirian mahasiswa memberikan nilai yang signifikan terhadap prestasi belajar mahasiswa.

\section{KESIMPULAN}

1. Sikap ilmiah memiliki kontribusi yang positif namun tidak signifikan terhadap prestasi belajar mahasiswa. Korelasi antara sikap ilmiah dan pretasi belajar mahasiswa tergolong sangat lemah. Sikap ilmiah 
hanya memberikan kontribusi sebesar $1,00 \%$ terhadap prestasi belajar mahasiswa.

2. Motivasi belajar memiliki kontribusi yang positif dan signifikan terhadap prestasi belajar mahasiswa. Korelasi antara motivasi belajar dan pretasi belajar mahasiswa tergolong lemah. Motivasi belajar hanya memberikan kontribusi sebesar $7,10 \%$ terhadap prestasi belajar mahasiswa.

3. Kemandirian belajar memiliki kontribusi yang positif dan signifikan terhadap prestasi belajar mahasiswa. Korelasi antara kemandirian belajar dan pretasi belajar mahasiswa tergolong lemah. Kemandirian belajar hanya memberikan kontribusi sebesar $5,10 \%$ terhadap prestasi belajar mahasiswa.

4. Sikap ilmiah, motivasi dan kemandirian belajar memiliki kontribusi yang positif dan signifikan terhadap prestasi belajar mahasiswa. Korelasi antara sikap ilmiah, motivasi dan kemandirian belajar terhadap pretasi belajar mahasiswa tergolong lemah. Sikap ilmiah, motivasi dan kemandirian belajar hanya memberikan kontribusi sebesar $8,80 \%$ terhadap prestasi belajar mahasiswa.

\section{SARAN}

Disarankan bagi para dosen untuk memberikan motivasi mahasiswa dalam belajar, melatih sikap ilmiah mahasiswa dan berusaha membentuk karakter mahasiswa yang mandiri dalam belajar. Bagi penelitian lanjutan disarankan untuk melihat pengaruh sikap ilmiah, motivasi belajar dan kemandirian belajar terhadap prestasi belajar mahasiswa.

\section{DAFTAR RUJUKAN}

Angkowo, R dan Kosasih, A. 2007. Optimalisasi Media Pembelajaran. Jakarta: Grafindo
Arikunto, Suharsimi. 2002. Dasar-dasar Evaluasi Pendidikan. Jakarta: Bumi Aksara.

Arikunto, Suharsimi. 2006. Prosedur Penelitian Suatu Pendekatan Praktek. Jakarta: Rineka Cipta.

Depdiknas. 2002. Kamus Besar Bahasa Indonesia. Jakarta: Balai Pustaka

Depdiknas. 2008. Konsep Sekolah Kategori Mandiri-Sekolah Standar Nasional. Jakarta: Direktorat Pembinaan Sekolah Menengah Atas.

Depdiknas. 2008. Pengembangan Perangkat Penilaian Afektif. Jakarta: Direktorat Pembinaan Sekolah Menengah Atas.

Depdiknas. 2008. Pengembangan Perangkat Penilaian Psikomotorik. Jakarta: Direktorat Pembinaan Sekolah Menengah Atas.

Dimyati dan Mudjiono. 2009. Belajar dan Pembelajaran. Jakarta: Rineka Cipta

Gie, The Liang. 1983. Cara Belajar yang Efisien. Yogyakarta: Gadjah Mada University Press.

Junjunan, Siti. 2009. Kontribusi Gaya Belajar Dan Kemandirian Belajar Terhadap Prestasi Belajar Matematika Siswa Sma Negeri Di Kota Bandung: Studi Analisis Deskriptif Terhadap Siswa Sma Negeri Kelas XI Ipa Berdasarkan Cluster Di Kota Bandung Tahun Ajaran 2008/2009. Skripsi FPMIPA UPI Bandung: tidak diterbitkan.

Margono. 2003. Strategi Belajar Mengajar. Surakarta: Sebelas Maret University

Purwanto, Ngalim. 1990. Psikologi Pendidikan. Bandung. Remaja Rosda Karya.

Sagala, Syaiful. 2010. Konsep dan Makna Pembelajaran. Bandung: Alfabeta.

Sanjaya, Wina. 2009. Strategi Pembelajaran, Berorientasi Standar Proses 
Pendidikan. Jakarta: Kencana Prenada Media Group.

Soemarsono. 2007. Strategi Belajar Mengajar.

Surakarta. Sebelas Maret University Press.

Sudjana, Nana. 2008. Penilaian Hasil Proses Belajar Mengajar. Bandung: Remaja Rosdakarya.

Sugiyono. 2007. Metode Penelitian Pendidikan. Bandung: Alfabeta.

Suparno, Paul. 2006. Metodologi Pembelajaran Fisika Kontruktivisme dan Menyenangkan. Yogyakarta: Kanisius

Supriatna, A. 2004. Penggunaan Sistem Pengajaran dalam Meningkatkan Kemandirian Belajar Siswa Pada Materi Peta di Kelas VI SDN Ciluncat II Kecamatan Banjaran Kabupaten Bandung. Skripsi Jurusan PGSD UPI Bandung: tidak diterbitkan.

Syamsuddin M, A. 1996. Psikologi Pendidikan. Bandung: Remaja Rosdakarya.
Ulum, Bahrul. 2007. Sikap Ilmiah. (Diambil pada tanggal 30 Desember 2012 tersedia di http://blogbahrul.wordpress.com).

Wadji, Badrul. 2011. Pembelajaran Fisika Menggunakan Strategi Peta Konsep (Concept Map) Dan Strategi PQ4R (Preview, Questions, Read, Reflect, Recite, And Review) Ditinjau Dari Motivasi Belajar Dan Tingkat Berfikir Abstrak Siswa. Tesis PPs UNS: tidak diterbitkan.

Wahyudi. 2011. Pembelajaran Fisika menggunakan Pendekatan Keterampilan Proses dengan Metode Inkuiri dan Eksperimen ditinjau dari Sikap Ilmiah dan Kemampuan Menggunakan Alat Ukur Listrik. Tesis PPS UNS: tidak diterbitkan. 